\title{
Exploring Gaps in Healthcare Workers Knowledge, Attitude, Perception and Practice of COVID-19 Prevention and Control in Rivers State Nigeria
}

\author{
Golden Owhonda ${ }^{1,2}$, Ifeoma Nwadiuto ${ }^{1,2}$, Omosivie Maduka ${ }^{2,3^{*}}\left(\mathbb{D}\right.$, Datonye Alasia ${ }^{2,4}$, \\ Charles Tobin-West ${ }^{2,3}$, Nyarawo Ekanem ${ }^{2,5}$, Chinenye Okafor ${ }^{2,6}$, Esther Azi ${ }^{2,7}$, Vetty Agala ${ }^{2,8}$, \\ Chibianotu Ojimah ${ }^{2,6}$, John Nwolim Paul ${ }^{1,2}$, Doris Nria' ${ }^{1,2}$, Ayo-Maria Olofinuka ${ }^{2,6}$, \\ Ifeoma Ndekwu ${ }^{2,9}$, Chikezie Opara ${ }^{2,9}$, Chris Newsom ${ }^{2,9}$
}

${ }^{1}$ Department of Public Health and Disease Control, Rivers State Ministry of Health, Port Harcourt, Nigeria

${ }^{2}$ Rivers State Public Health Emergency Operations Centre, Port Harcourt, Nigeria

${ }^{3}$ Department of Preventive and Social Medicine, University of Port Harcourt, Port Harcourt, Nigeria

${ }^{4}$ Department of Internal Medicine, University of Port Harcourt, Port Harcourt, Nigeria

${ }^{5}$ Department of Disease Control, Rivers State Primary Health Care Management Board, Port Harcourt, Nigeria

${ }^{6}$ World Health Organization, Rivers State Field Office, Port Harcourt, Nigeria

${ }^{7}$ Department of Community Medicine, Rivers State University, Port Harcourt, Nigeria

${ }^{8}$ Rivers State Hospital Management Board, Port Harcourt, Nigeria

${ }^{9}$ Stakeholder Democracy Network, Port Harcourt, Nigeria

Email: *omosivie.maduka@uniport.edu.ng

How to cite this paper: Owhonda, G., Nwadiuto, I., Maduka, O., Alasia, D., Tobin-West, C., Ekanem, N., Okafor, C., Azi, E., Agala, V., Ojimah, C., Paul, J.N., Nria, D., Olofinuka, A.-M., Ndekwu, I., Opara, C. and Newsom, C. (2021) Exploring Gaps in Healthcare Workers Knowledge, Attitude, Perception and Practice of COVID-19 Prevention and Control in Rivers State Nigeria. Advances in Infectious Diseases, 11, 140-155. https://doi.org/10.4236/aid.2021.112014

Received: February 17, 2021

Accepted: April 16, 2021

Published: April 19, 2021

\begin{abstract}
Background Knowledge, attitude, perception, and practice of Covid-19 prevention affect the effectiveness of healthcare workers in the pandemic response. This study assessed gaps in awareness, knowledge, attitude, perception, and practice of Covid-19 prevention among healthcare workers in Rivers State, Nigeria. Methods This was a descriptive cross-sectional survey carried out six weeks into Rivers State response that commenced on February 20, 2020, in the 23 Local Government Areas (LGAs). State Disease Surveillance and Notification Officers used multistage sampling to recruit 555 healthcare workers for the survey. A self-designed structured interviewer-administered questionnaire built into the Open Data Kit application for android phones was used for data collection. Descriptive data analysis was done, and outputs presented as frequency and percentages. Results There was a total of 372 (67.0\%) female respondents. Majority of study participants had tertiary education 453 (81.6\%). The mean age of study participants was 40.6 years (Standard Deviation $=7.8$ years). Furthermore, $285(51.4 \%)$ were Community
\end{abstract}


Copyright $\odot 2021$ by author(s) and Scientific Research Publishing Inc. This work is licensed under the Creative Commons Attribution International License (CC BY 4.0).

http://creativecommons.org/licenses/by/4.0/ (c) (i) Open Access
Health Workers, and had over ten years practicing experience 393 (70.8\%). Most healthcare workers 554 (99.8\%) had heard about Covid-19, through radio 539 (97.1\%), and television 445 (80.2\%) yet 213 (38.4\%) respondents did not know that it is caused by a virus. Most respondents $415(74.8 \%)$ had good knowledge about Covid-19. However, only 148 (26.7\%) would refer suspected cases to a facility and only $365(65.8 \%)$ respondents demonstrated the correct hand washing technique. Conclusion There are some gaps in health worker knowledge, attitude, perception, and practice of Covid-19 prevention. Interventions to bridge these gaps are needed for effective containment of this pandemic.

\section{Keywords}

Knowledge, Attitude, Perception, Practice, Healthcare Workers, Covid-19

\section{Introduction}

A pandemic is the worldwide spread of a new disease. The last notable pandemic occurred in 1918 caused by an H1N1 virus with genes of avian origin [1]. It is estimated that about 500 million people or one-third of the world's population were infected with this virus. Although there is no specific record of the statistics of the health workers who were infected, but there are speculations that a lot of health workers would have been infected as the pandemic spanned for nearly a year (1918-1919) [1].

Coronavirus disease (COVID-19) caused by severe acute respiratory syndrome: coronavirus 2 (SARS-CoV-2) virus, which was initially considered a pneumonia of unknown cause broke out in Wuhan, China on the $31^{\text {st }}$ of December 2019 [2]. The disease was later declared a Public Health Emergency of International Concern on the 30th of January 2020 and eventually a pandemic on the 11th of March 2020 due to the alarming levels of spread and severity [3]. Globally, a total of 152,888 COVID-19 infections and 1413 deaths had been reported as of August 2020. Infections were mainly in women $(71.6 \%, \mathrm{n}=14,058)$ and nurses $(38.6 \%, \mathrm{n}=10,706)$, but deaths were mainly in men $(70.8 \%, \mathrm{n}=550)$ and doctors $(51.4 \%, \mathrm{n}=525)$. Limited data suggested that general practitioners and mental health nurses were the highest risk specialties for deaths. In Africa, there are more than 10,000 health workers in the 40 countries which reported to have been infected with COVID-19 [4]. In Nigeria, as at August 2020, 2175 health workers had been infected with COVID-19, while in Rivers State, 122 health workers (97 in public and 25 in private facilities) had been infected with COVID-19. The 122 health workers infected in Rivers State are thus: 69 doctors, 31 nurses, 5 laboratory scientists, 2 health attendants and others 5 [5]. The State had her index case of COVID-19 on March 25, but as of 11th August 2020 had recorded 1972 confirmed cases of COVID-19 according to Nigerian Centre for Diseases Control (NCDC) [6]. 
Health workers are at the front line of the COVID-19 outbreak response and as such are exposed to hazards which include pathogen exposure, long working hours, psychological distress, fatigue, occupational burnout, stigma, and physical and psychological violence [7] [8]. These hazards predispose health workers to infection and contribute to the rising number of cases globally. In Rivers State as of $11^{\text {th }}$ August 2020, a total of 106 health workers were infected with Covid-19 with three deaths. Knowledge is a prerequisite for establishing prevention beliefs, forming positive attitudes, and promoting positive behaviours. Individuals' cognition and attitudes towards disease affect the effectiveness of their coping strategies behaviour and practice [9].

Literature shows that there is available information on the findings from studies done in China, Pakistan and Nigeria on awareness, attitude, and other characteristics of COVID 19 [2] [7] [10] [11] [12] [13] [14]. However, few studies have been published in South-South Nigeria. Hence, this study was carried out six weeks into the pandemic response in Rivers State (which commenced on the $20^{\text {th }}$ of February 2020) to assess the knowledge, attitude, perception, and practice of Covid-19 prevention among healthcare workers in Rivers State, Nigeria. Survey findings would identify gaps in the knowledge of COVID-19 transmission and symptoms among health workers across Rivers State as was seen in published studies outside Nigeria [14] [15].

\section{Methodology}

\subsection{Study Area, Design and Population}

Rivers State is in Southern Nigeria. It has a population of more than five million according to census data released in 2006. The state is economically significant as the centre of Nigeria's oil industry, bounded by the states of Anambra and Imo on the north, Abia and Akwa Ibom on the east, and Bayelsa and Delta on the west.

The survey took place in the 23 Local Government Areas (LGAs) of Rivers State. It was a descriptive cross-sectional survey that was carried out about six weeks into Rivers State pandemic response, that began on February 20, 2020. The study population consisted of healthcare workers at primary, secondary, and tertiary healthcare facilities in the public and private sectors of the state who were available at the facilities and gave informed consent for the survey. All health workers who were on leave were excluded from the survey.

\subsection{Sample Size and Sampling Technique}

The minimum sample size was calculated as 427 healthcare workers across Rivers State based on the sample size formula for single proportions [17] where the prevalence of good knowledge about Covid-19 was set at 50\% (since there is no previously established prevalence), degree of accuracy set at $5 \%$ and $10 \%$ non-response rate. Multistage sampling technique was used. In the first stage, a list of all the wards that have health facilities in each LGA was prepared and 
three wards were selected from each LGA by simple random sampling. In the second stage, one health facility was selected from each ward by simple random sampling. Forwards that had only one health facility, the health facility was automatically included into the study. In the third stage, six or ten healthcare workers were selected from health facilities with less than 30 and 30 or more health workers respectively, by simple random sampling, using the nominal roll as the sampling frame. A total of 555 healthcare workers were selected from 69 health facilities across the 23 LGAs in Rivers State.

\subsection{Data Management}

The data collection tool was a self-designed interviewer-administered four-page questionnaire that was built into the Open Data Kit (ODK) application for android phones with Global Positioning System (GPS) tracking. Data collection was done by the Disease Surveillance and Notification Officer (DSNO) of each of the LGAs in the state. The choice of this set of data collectors was informed by the restriction of movement during the lockdown phase of the pandemic. The DSNOs were also trained in data collection and are familiar with the terrain and the community. Data collectors were trained for one day on the administration of the tool before it was rolled out. The entered data was downloaded into an excel file, exported to IBM SPSS version 23, and analysed. Major outcome variables included knowledge of Covid-19, attitude towards Covid-19 prevention, perception of Covid-19 prevention, and practice of Covid-19 prevention methods. Descriptive statistics was done, and results were presented as tables. A total of six questions were used to assess knowledge. Some of the knowledge questions accommodated multiple responses, giving a total of 31 responses. To compute for knowledge score, all correct responses to knowledge questions were scored as one, while wrong responses were scored as zero thus maximum score was 31 . The respondents' scores were summed up, divided by the maximum score of 31 , and multiplied by 100 to express knowledge score as a percentage. Respondents who scored $0 \%-49.9 \%$ were classified as having poor knowledge, those who scored $50 \%-79.9 \%$ were classified as having good knowledge, while those who scored $80 \%$ and above were classified as having excellent knowledge. For handwashing practice, each respondent was asked to demonstrate how they washed their hands, while the interviewer observed to see if the respondent washed all six critical areas of the hands (between the fingers, washing the back of fingers, washing the back of the hand, washing the palm, washing base of the thumb, washing the fingernails), and ticked accordingly using an observational checklist built on the ODK platform. Those who demonstrated washing all six critical areas of the hands were scored 6/6 (100\%) and classified as showing correct handwashing practice, while those who failed to demonstrate washing at least one of the six critical areas were classified as showing incorrect handwashing practice.

\subsection{Ethical Considerations}

Ethics approval was obtained from the Research Ethics Committee of the Rivers 
State Ministry of Health (MH/PRS/391/VOL.2/675). Informed consent was built into the data collection tool such that the survey was truncated if any participant declined to provide verbal consent or withdrew consent at any time during the interview. Confidentiality was assured by anonymizing the data collection tool. In addition, filled forms were uploaded into a World Health Organization secured server with access restricted to the research team.

\section{Results}

\subsection{Sociodemographic and Work Characteristics}

A total of 555 healthcare workers gave consent and participated in the study. Among the 555 healthcare workers interviewed, 183 (33.0\%) were males, had tertiary education 453 (81.6\%), and were married 432 (77.8\%). Their ages ranged between 20 and 65 years, with a mean age of 40.6 years (Standard Deviation = 7.8 years) Table 1 .

Table 1. Socio-demographic characteristics of study participants.

\begin{tabular}{|c|c|c|}
\hline Variables & Frequency $(n=555)$ & Percentage \\
\hline \multicolumn{3}{|l|}{ Age group (years) } \\
\hline$<25$ & 10 & 1.8 \\
\hline $25-34$ & 97 & 17.5 \\
\hline $35-44$ & 275 & 49.5 \\
\hline $45-54$ & 152 & 27.4 \\
\hline $55-64$ & 19 & 3.4 \\
\hline 65 and above & 2 & 0.4 \\
\hline Mean Age \pm SD & & \\
\hline \multicolumn{3}{|l|}{ Gender } \\
\hline Male & 183 & 33.0 \\
\hline Female & 372 & 67.0 \\
\hline \multicolumn{3}{|l|}{ Religion } \\
\hline Christian & 553 & 99.6 \\
\hline Islam & 1 & 0.2 \\
\hline Other & 1 & 0.2 \\
\hline \multicolumn{3}{|l|}{ Educational level } \\
\hline Primary & 19 & 3.4 \\
\hline Secondary & 48 & 8.6 \\
\hline Tertiary & 453 & 81.6 \\
\hline Post Tertiary & 35 & 6.3 \\
\hline \multicolumn{3}{|l|}{ Marital status } \\
\hline Single & 111 & 20.0 \\
\hline Married & 432 & 77.8 \\
\hline Divorced/Separated & 6 & 1.1 \\
\hline Widowed & 6 & 1.1 \\
\hline
\end{tabular}

$\mathrm{SD}=$ Standard Deviation 
The health workers were of different cadre, but more than half 285 (51.4\%) of them were community health workers. Many 377 (67.9\%) of the respondents were at the senior-level staff with $393(70.8 \%)$ having over ten years of practicing experience. The median number of years of practice was 15 years with interquartile range of 10 years. Most of the respondents 525 (94.4\%) worked in public health facilities, with $464(83.6 \%)$ predominantly in primary health care centre Table 2.

Table 2. Work characteristics of study participants.

\begin{tabular}{|c|c|c|}
\hline & Frequency $(n=555)$ & Percentage \\
\hline \multicolumn{3}{|l|}{ Cadre of health worker } \\
\hline Doctor/Dentist & 27 & 4.9 \\
\hline Nurse/Midwife & 73 & 13.2 \\
\hline Pharmacist & 52 & 9.4 \\
\hline Medical Laboratory Scientist & 78 & 14.1 \\
\hline Community Health Officer & 285 & 51.4 \\
\hline Physiotherapist/Optometrist & 1 & 0.2 \\
\hline Hospital Admin/Finance/Support Services & 15 & 2.7 \\
\hline Others & 24 & 4.3 \\
\hline \multicolumn{3}{|l|}{ Year in profession } \\
\hline$<5$ & 35 & 6.3 \\
\hline $5-10$ & 127 & 22.9 \\
\hline $11-20$ & 256 & 46.1 \\
\hline Over 20 & 137 & 24.7 \\
\hline Median (IQR) (years) & $15.0(10.0)$ & \\
\hline \multicolumn{3}{|l|}{ Professional level } \\
\hline Entry level/Intern & 3 & 0.5 \\
\hline Junior Staff & 144 & 25.9 \\
\hline Mid-Level (Resident) & 15 & 2.7 \\
\hline Senior Level (Senior Staff Position) & 377 & 67.9 \\
\hline Management (Head of Department or Unit or Higher) & 16 & 2.9 \\
\hline \multicolumn{3}{|l|}{ Ownership of health facility } \\
\hline Public & 524 & 94.4 \\
\hline Private & 29 & 5.2 \\
\hline Public/Private Partnership & 2 & 0.4 \\
\hline \multicolumn{3}{|l|}{ Level of health facility } \\
\hline Primary & 464 & 83.6 \\
\hline Secondary & 72 & 13 \\
\hline Tertiary & 19 & 3.4 \\
\hline
\end{tabular}

Others (Biochemist, Microbiologist, Health Information Officer, Health Attendant, Volunteer, Security, Cleaner). 


\subsection{Awareness and Knowledge of Covid-19}

Five hundred and fifty-four (99.8\%) of the respondents had heard of COVID-19. The four most common sources of information about COVID-19 were radio 539 (97.1\%), television $445(80.2 \%)$, health facility $380(68.5 \%)$, and social media 375 (67.6\%) respectively Table 3.

Three hundred and forty-two (61.7\%) of the respondents were aware that COVID-19 is caused by a virus, 115 (20.8\%) attributed COVID-19 to causes other than a virus, while 97 (17.5\%) reported not knowing the cause of the disease. Five hundred and twenty-two (94.2\%) of the respondents were aware that COVID-19 signs and symptoms manifest between $2^{\text {nd }}$ and $14^{\text {th }}$ day after contact, 519 (93.7\%) reported that there is no specific drug or remedy to treat COVID-19, and $533(96.2 \%)$ reported that there is no specific vaccine for COVID-19. Most 523 (94.4\%) of the respondents correctly classified a suspected case of COVID-19 as a person who had contact with a person who is sick of Coronavirus disease. The most frequently reported signs and symptoms of COVID-19 were fever 541 (97.7\%), cough 527 (95.1\%), difficulty in breathing 525 (94.8\%). Overall, 145 (74.9\%) respondents had good knowledge, while 62 (11.2\%) had excellent knowledge about Covid-19 Table 4.

Table 3. Awareness about COVID-19 among study participants.

\begin{tabular}{|c|c|c|}
\hline & Frequency & Percentage \\
\hline \multicolumn{3}{|l|}{ Heard of COVID-19 $(n=555)$} \\
\hline No & 1 & 0.2 \\
\hline Yes & 554 & 99.8 \\
\hline \multicolumn{3}{|l|}{ Source of information about COVID-19* $(n=554)$} \\
\hline Radio & 539 & 97.3 \\
\hline Television & 445 & 80.3 \\
\hline Health facility & 380 & 68.6 \\
\hline Social media (Facebook, Twitter, WhatsApp) & 375 & 67.7 \\
\hline Fliers & 328 & 59.2 \\
\hline GSM/SMS & 323 & 58.3 \\
\hline Church & 300 & 54.2 \\
\hline Health Educator & 296 & 53.4 \\
\hline Town announcer & 268 & 48.4 \\
\hline Newspaper & 264 & 47.7 \\
\hline Family member & 257 & 46.4 \\
\hline Peer/friends & 251 & 45.3 \\
\hline Internet sites & 238 & 43.0 \\
\hline Journal & 187 & 33.8 \\
\hline Market & 173 & 31.2 \\
\hline Neighbourhood & 149 & 26.9 \\
\hline Mosque & 57 & 10.3 \\
\hline Others & 6 & 1.1 \\
\hline
\end{tabular}

* = Multiple response; Others (School, Training). 
Table 4. Knowledge about COVID-19 among study participants.

\begin{tabular}{|c|c|c|}
\hline & Frequency $(n=554)$ & Percentage \\
\hline \multicolumn{3}{|l|}{ Causes of COVID-19 } \\
\hline Virus & 342 & 61.7 \\
\hline Causes other than a virus & 115 & 20.8 \\
\hline I don't know & 97 & 17.5 \\
\hline \multicolumn{3}{|l|}{$\begin{array}{l}\text { Time of manifestation of signs and symptoms of } \\
\text { COVID-19 }\end{array}$} \\
\hline Less than 2 days & 5 & 0.9 \\
\hline Between 2 and 14 days & 522 & 94.2 \\
\hline More than 14 days & 10 & 1.8 \\
\hline I don't know & 17 & 3.1 \\
\hline \multicolumn{3}{|l|}{ There is specific drug or remedy to treat COVID-19 } \\
\hline No & 519 & 93.7 \\
\hline Yes & 10 & 1.8 \\
\hline I don't know & 25 & 4.5 \\
\hline \multicolumn{3}{|l|}{ There is a specific vaccine to prevent COVID-19 } \\
\hline No & 533 & 96.2 \\
\hline Yes & 4 & 0.7 \\
\hline I don't know & 17 & 3.1 \\
\hline \multicolumn{3}{|l|}{ Suspected case of COVID-19* } \\
\hline $\begin{array}{l}\text { A person who had contact with a person } \\
\text { who is sick of Coronavirus disease }\end{array}$ & 523 & 94.4 \\
\hline $\begin{array}{l}\text { A person who travelled back from } \\
\text { Coronavirus disease high-risk country } \\
\text { or city but shows no symptom of the disease }\end{array}$ & 487 & 87.9 \\
\hline $\begin{array}{l}\text { A person with a fever plus one or } \\
\text { more symptoms of respiratory diseases }\end{array}$ & 434 & 78.3 \\
\hline $\begin{array}{l}\text { A person with fever or without } \\
\text { symptoms of a respiratory disease like } \\
\text { cough and shortness of breath }\end{array}$ & 230 & 41.5 \\
\hline $\begin{array}{l}\text { Person coughing and sneezing with no } \\
\text { history of travel from high-risk country } \\
\text { nor contact with coronavirus disease patient }\end{array}$ & 305 & 55.1 \\
\hline $\begin{array}{l}\text { A person who had contact with a } \\
\text { person that died with } \\
\text { symptoms of Coronavirus disease }\end{array}$ & 411 & 74.2 \\
\hline $\begin{array}{l}\text { A person who had contact with a person } \\
\text { suspected of having Coronavirus disease } \\
\text { but yet to be laboratory confirmed }\end{array}$ & 387 & 69.9 \\
\hline \multicolumn{3}{|l|}{ Signs and symptoms of COVID-19* } \\
\hline Fever & 541 & 97.7 \\
\hline
\end{tabular}




\begin{tabular}{ccc} 
Continued & & \\
\hline Cough & 527 & 95.1 \\
Difficulty in breathing & 525 & 94.8 \\
Sore throat & 403 & 72.7 \\
Weakness & 317 & 57.2 \\
Headache & 288 & 52.0 \\
A general feeling of unwell & 275 & 49.6 \\
Body pains & 150 & 27.1 \\
Diarrhoea & 118 & 21.3 \\
Vomiting & 72 & 13.0 \\
Rash on the body & 47 & 8.5 \\
Knowledge Score & & 13.9 \\
Poor & 77 & 74.9 \\
Fair & 415 & 11.2 \\
Good & 62 & \\
\hline & & \\
\hline
\end{tabular}

${ }^{*}=$ Multiple response.

\subsection{Attitude towards Covid-19 Prevention and Control Activities}

Most 541 (97.7\%) health workers would call the COVID-19 helplines when they see a suspected case of COVID-19, 148 (26.7\%) would refer the patient to another health facility, while 64 (11.6\%) would admit the patient immediately and commence treatment. A total of $532(96.0 \%)$ respondents would call the COVID-19 helpline if they develop signs and symptoms of the virus. Four hundred and eighty (86.6\%) of health workers asserted that they would live or work with a person with COVID-19 who has been treated, tested negative, and discharged Table 5.

\subsection{Perception about Covid-19 Prevention and Control Activities}

Five hundred and thirty-five (96.4\%) of the respondents opined that COVID-19 is a problem in the state, $390(70.3 \%)$ felt that they can contract the virus, and $113(20.3 \%)$ feel the government is not doing enough to contain the virus Table 6.

\subsection{Practice of Covid-19 Prevention}

Health workers were asked to demonstrate hand washing as a safe practice for COVID-19 prevention, 525 (94.6\%) washed between the fingers, 478 (86.1\%) washed the back of fingers, $470(84.7 \%)$ washed the back of the hand, 463 (83.4\%) washed the palm, 447 (80.5\%) washed the base of the thumb and, 437 (78.7\%) washed the fingernails. However, $365(65.8 \%)$ of the respondents washed all critical parts of hands and were scored 100\% Table 7. 
Table 5. Health worker's attitude towards COVID-19.

Frequency $(n=554) \quad$ Percentage

What I'll do when you see a COVID-19 patient*

Call the COVID-19 helplines

Refer to another health facility

Admit patients immediately

and commence treatment

Mind my business

Send the patient away from the health facility

Do not see patients

Others

\section{What I'll do when I develop signs and symptoms of COVID-19*}

Call the coronavirus help number

Go to the hospital

Stay at home

Pray

Treat myself

Go to a traditional healer

Hide

Others

What I'll advice a family member, relative or neighbour who develops signs and symptoms of COVID-19*

Call the coronavirus help number

Go to the hospital

Stay at home

Pray

Go to a traditional healer

Home treatment

Hide

Go to a religious centre

Do nothing
I would live or work with a person with COVD-19 who has been treated, tested negative and discharged 
Table 6. Health worker's perception towards COVID-19.

Frequency $(\mathrm{n}=554) \quad$ Percentage

COVID-19 is a problem in Rivers State

No

Yes

I don't know

Reasons why COVID-19 is not a

problem in Rivers State $(\mathrm{n}=10)^{*}$

There are only a few cases

It is just being exaggerated

Others

Reasons why COVID-19 is a

problem in Rivers State $(\mathrm{n}=535)^{*}$

It is highly infectious

It has affected activities in the state

It has no cure

It is a deadly disease

It creates a lot of panic

It is an attack from the Western world

Others

Do you think you can contract COVID-19

$$
\text { No }
$$

Yes

I don't know

Why you think you cannot

contract COVID-19 $(\mathrm{n}=140)^{*}$

I observe all the preventive measures

I am very careful

It is not my portion (my faith protects me)

Coronavirus does not exist

Others

Think the government is doing

enough to contain the COVID-19 outbreak

$$
\text { No }
$$

Yes

I don't know
432

80.7

${ }^{\star}$ Multiple response. 
Table 7. Health workers practice regarding COVID 19 prevention.

\begin{tabular}{|c|c|c|}
\hline & Frequency $(n=554)$ & Percentage \\
\hline \multicolumn{3}{|l|}{ How you prevent yourself from getting COVID-19* } \\
\hline Regular hand washing with soap and water & 529 & 95.5 \\
\hline $\begin{array}{l}\text { By keeping your distance from any } \\
\text { person with suspected Coronavirus disease }\end{array}$ & 521 & 94.0 \\
\hline Regular use of hand sanitizer & 402 & 72.6 \\
\hline Wearing face or nose masks & 378 & 68.2 \\
\hline $\begin{array}{l}\text { Avoid touching your mouth, nose, } \\
\text { and eyes with unwashed hands }\end{array}$ & 377 & 68.1 \\
\hline Avoid crowded places or events & 358 & 64.6 \\
\hline Wearing hand gloves & 326 & 58.8 \\
\hline Staying at home & 293 & 52.9 \\
\hline Avoid air-conditioned room, office, or car & 39 & 7.0 \\
\hline Regular handing with water only & 36 & 6.5 \\
\hline Regular gargling or drinking of water & 28 & 5.1 \\
\hline Avoid cold food and drinks & 25 & 4.5 \\
\hline Bathing with hot or warm water & 18 & 3.2 \\
\hline Drinking concoctions (lime, ginger, garlic, etc) & 15 & 2.7 \\
\hline Avoid eating bush meat & 13 & 2.3 \\
\hline Drinking alcoholic gins or hot drinks & 12 & 2.2 \\
\hline Talking chloroquine & 10 & 1.8 \\
\hline Going for special prayers & 7 & 1.3 \\
\hline Bathing with saltwater & 5 & 0.9 \\
\hline Eating bitter kola & 3 & 0.5 \\
\hline I don't know & 7 & 1.3 \\
\hline \multicolumn{3}{|l|}{ Hand washing practice* } \\
\hline Washing between the fingers & 525 & 94.8 \\
\hline Washing the back of fingers & 478 & 86.3 \\
\hline Washing the back of the hand & 470 & 84.8 \\
\hline Washing the palm & 463 & 83.6 \\
\hline Washing base of the thumb & 447 & 80.7 \\
\hline Washing the fingernails & 437 & 78.8 \\
\hline \multicolumn{3}{|l|}{ Overall hand washing practice } \\
\hline Correct & 365 & 65.9 \\
\hline Incorrect & 189 & 34.1 \\
\hline
\end{tabular}

* $=$ Multiple response. 


\section{Discussion}

This research provides insights into gaps in awareness, knowledge, attitude, perception, and practice of Covid-19 prevention among health care workers in Rivers State. Most healthcare workers had heard about Covid-19. However, their source of information at the time of the survey was mostly through radio and television. This finding on source of information, agrees with that of other researchers [2] [3] [7] [9]. This reflects the effectiveness and influence of broadcast media in disseminating information to the public. It is therefore important that the pandemic response collaborates with broadcast media agencies to ensure right and consistent messaging for COVID-19 prevention.

Most of the respondents were aware of COVID-19, however a third of respondents did not know that it is caused by a virus. This alludes to the fact that there is a gap in knowledge of the aetiology of the disease. This gap may be because of the paucity of non-technical sources of information about the disease. This gap in knowledge could have deleterious effect on the risk perception, attitude, and behaviour of these health workers. While almost all respondents claimed they would call the NCDC phone lines for suspected cases, one-tenth of respondents will treat the suspected case themselves. This finding is corroborated by the findings of other researchers who reported similar attitude of respondents [10] [12] [13] [14] [15]. This demonstrates a gap in attitude towards COVID-19 and can lead to unnecessary risk taking in managing suspected or confirmed cases of the disease. There were also about one-fifth of all respondents have the perception that government authorities are not doing enough to curb the pandemic. This perception exposes a distrust in government and has the potential to facilitate an unwillingness among health workers to go the extra mile in implementing prevention and control measures against COVID-19. Finally, whereas it is expected that all health workers are competent in all the handwashing steps, only two-thirds of respondents demonstrated the correct handwashing technique.

The findings of this survey viz-a-viz similar research underscore the need for cascade training at all levels of healthcare such that correct knowledge and information about aetiology and disease transmission dynamics is imparted to healthcare workers who will, in turn, be veritable sources of information to the public. Accurate knowledge empowers healthcare workers to respond safely and effectively as an antidote to fear-driven responses such as turning patients away from health facilities. As seen in this study, social media is not yet a pervasive source of information at the healthcare facilities in the local government areas of the state unlike more developed climes such as Europe and the US [15] [17]. However, the major means of communication from the National Centre for Disease Control (NCDC) is social media. This implies a gap between the provision of information and guidance and access to this information which has resulted in health workers and the masses in many rural communities not utilizing the information provided. Although there are ample information, education, 
and communication materials on the NCDC website, these need to be printed as posters, handbills, infographics, other materials especially for community-based education for healthcare workers. The gaps identified in attitude, perception, and preventive practices will be best addressed through risk communication activities targeted at boosting knowledge, and confidence of healthcare workers in Covid-19 prevention. Health workers with good knowledge, attitudes, and practice of Covid-19 prevention are less likely to get infected with the SARS-Cov-2 virus.

This survey was carried out among many healthcare workers across all the Local Government Areas of the state with responses that cut across primary and secondary facilities. This is a strength of this study because the results are generalizable to similar populations. A limitation of this study however is the cross-sectional nature of data collection which was done six weeks into the state outbreak response. The dynamic nature of this pandemic and its response implies that a lot of changes in knowledge, attitude, perception, and practice could have occurred after the survey. A follow-up survey would be needed to access any changes that may have occurred. Finally, the findings from this study are relevant to all pandemic response teams in Nigeria and Sub-Saharan Africa for purposes of planning gap bridging interventions in knowledge, attitude, and practice of Covid-19. These findings can also be projected to the response to other highly pathogenic infectious diseases.

\section{Conclusion}

This survey highlights some gaps in knowledge, attitude, perception and practice of COVID-19 prevention among health workers at primary and secondary healthcare facilities in Rivers State. Interventions are needed to bridge the gaps identified because ensuring that healthcare workers have excellent knowledge, attitude, and practice of Covid-19 prevention and control is imperative for a successful response.

\section{Acknowledgements}

Disease Surveillance and Notification Officers of the Rivers State Primary Health Care Management Board for their role in data collection, Stakeholder Democracy Network for funding the survey, and the Technical and Administrative Staff of the Rivers State Public Health Emergency Operations Centre for the key roles they play in the pandemic response.

\section{Authors' Contributions}

OM conceptualized the research, wrote the research protocol, the first draft of the data collection tool, and the final manuscript.

GO, IN, OM, DA, CT-W, CO, JNP, and CO reviewed and fine-tuned the research concept, the research protocol, data collection tools and all drafts of the manuscript. 
OM, VA, EA, NE, DN, CO, IN, CO, and CN supported the training of the data collectors, supervision of field activities and reviewed the final draft and manuscript.

$\mathrm{OM}, \mathrm{CO}, \mathrm{AO}$ analyzed the data set, wrote up the results section and critically reviewed the final manuscript.

All authors approved the final draft of the manuscript.

\section{Funding}

This research supported by collaborative partnership and funding from the Stakeholder Democracy Network, a UK registered Charity. No. 1148143.

\section{Conflicts of Interest}

The authors declare no conflicts of interest regarding the publication of this paper.

\section{References}

[1] Jester, B.G., Uyeki, T.M., Jernigan, D.B. and Tumpey, T.M. (2019) Historical and Clinical Aspects of the 1918 H1N1 Pandemic in the United States. Virology, 527, 32-37. https://doi.org/10.1016/j.virol.2018.10.019

[2] Yang, J., Zheng, Y., Gou, X., Pu, K., Chen, Z., Guo, Q., et al. (2020) Prevalence of Comorbidities and Its Effects in Patients Infected with SARS-CoV-2: A Systematic Review and Meta-Analysis. International Journal of Infectious Diseases, 94, 91-95. https://linkinghub.elsevier.com/retrieve/pii/S1201971220301363 https://doi.org/10.1016/j.ijid.2020.03.017

[3] Sohrabi, C., Alsafi, Z., O’Neill, N., Khan, M., Kerwan, A., Al-Jabir, A., et al. (2020) World Health Organization Declares Global Emergency: A Review of the 2019 Novel Coronavirus (COVID-19). International Journal of Surgery, 76, 71-76. https://doi.org/10.1016/j.ijsu.2020.02.034

[4] World Health Organization (2020) Over 10,000 Health Workers in Africa Infected with COVID-19.

https://www.afro.who.int/news/over-10-000-health-workers-africa-infected-covid-1 $\underline{9}$

[5] Rivers PHEOC (2019) The Official Twitter Handle of Rivers State, Public Health Emergency Operations Centre (PHEOC). https://twitter.com/riverspheoc?lang=en

[6] Nigeria Centre for Disease Control (2020) National and State Covid-19 Daily Situation Reports. Twitter. https://twitter.com/ncdcgov?lang=en

[7] Zhang, M., Zhou, M., Tang, F., Wang, Y., Nie, H., Zhang, L., et al. (2020) Knowledge, Attitude, and Practice Regarding COVID-19 among Healthcare Workers in Henan, China. Journal of Hospital Infection, 105, 183-187.

https://linkinghub.elsevier.com/retrieve/pii/S0195670120301870 https://doi.org/10.1016/j.jhin.2020.04.012

[8] World Health Organization (2020) Coronavirus Disease (Covid-19) Outbreak: Rights, Roles and Responsibilities of Health Workers, Including Key Considerations for Occupational Safety. World Health Organization, Geneva, 1-3. https://www.who.int/emergencies/diseases/novel-coronavirus-2019

[9] Jiang, L., Ng, I.H.L., Hou, Y., Li, D., Tan, L.W.L., Ho, H.J.A., et al. (2018) Infectious Disease Transmission: Survey of Contacts between Hospital-Based Healthcare 
Workers and Working Adults from the General Population. Journal of Hospital Infection, 98, 404-411. https://doi.org/10.1016/j.jhin.2017.10.020

[10] Wolf, M.S., Serper, M., Opsasnick, L., O’Conor, R.M., Curtis, L., Benavente, J.Y., et al. (2020) Awareness, Attitudes, and Actions Related to COVID-19 Among Adults with Chronic Conditions at the Onset of the U.S. Outbreak: A Cross-Sectional Survey. Annals of Internal Medicine, 173, 100-109. https://doi.org/10.7326/M20-1239

[11] Lai, C., Shih, T., Ko, W., Tang, H. and Hsueh, P. (2020) Severe Acute Respiratory Syndrome Coronavirus 2 (SARS-CoV-2) and Coronavirus Disease-2019 (COVID-19): The Epidemic and the Challenges. International Journal of Antimicrobial Agents, 55, Article ID: 105924. https://doi.org/10.1016/j.ijantimicag.2020.105924 https://linkinghub.elsevier.com/retrieve/pii/S0924857920300674

[12] Saqlain, M., Munir, M.M., Rehman, S.U., Gulzar, A., Naz, S., Ahmed, Z., et al. (2020) Knowledge, Attitude, Practice and Perceived Barriers among Healthcare Workers Regarding COVID-19: A Cross-Sectional Survey from Pakistan. Journal of Hospital Infection, 105, 419-423. https://doi.org/10.1016/j.jhin.2020.05.007

[13] Ogolodom, M., Mbaba, N., Alazigha, N., Erondu, O., Egbe, N., Golden, I., et al. (2020) Knowledge, Attitudes and Fears of HealthCare Workers towards the Corona Virus Disease (COVID-19) Pandemic in South-South, Nigeria. Health Science Journal, 19, 1-10.

[14] Huynh, G., Nguyen, T., Tran, V., Vo, K., Vo, V. and Pham, L. (2020) Knowledge and Attitude toward COVID-19 among Healthcare Workers at District 2 Hospital, Ho Chi Minh City. Asian Pacific Journal of Tropical Medicine, 13, 260-265. https://doi.org/10.4103/1995-7645.280396

[15] Chan, A.K.M., Nickson, C.P., Rudolph, J.W., Lee, A. and Joynt, G.M. (2020) Social Media for Rapid Knowledge Dissemination: Early Experience from the COVID-19 Pandemic. Anaesthesia, 75, 1579-1582. https://doi.org/10.1111/anae.15057

[16] Bryan, K. (2019) Epidemiology and Biostatistics: An Introduction to Clinical Research-The Textbook and the Workbook. Springer, New York City.

[17] Bhagavathula, A.S., Aldhaleei, W.A., Rahmani, J., Mahabadi, M.A. and Bandari, D.K. (2020) Novel Coronavirus (COVID-19) Knowledge and Perceptions: A Survey of Healthcare Workers. medRxiv. https://doi.org/10.1101/2020.03.09.20033381 